\title{
Efficacy of Core-Stabilization Exercise and Its Comparison with Home-Based Conventional Exercise in Low Back Pain Patients
}

\author{
Bel Ağrılı Hastalarda Core Stabilizasyon Egzersizi Etkinliği ve Konvansiyonel Ev \\ Egzersiz Programı ile Karșılaștırılması
}

\author{
Alev ALP' ${ }^{1}$, Gönen MENGi' ${ }^{1}$, Ahmet Hazım AVŞAROĞLU ${ }^{1}$, Muharrem MERT ${ }^{1}$, Deniz SIĞIRLI² \\ 'Department of Physical Therapy and Rehabilitation, Uludag University Faculty of Medicine, Bursa, Turkey \\ ${ }^{2}$ Department of Biostatistics, Uludağ University Faculty of Medicine, Bursa, Turkey
}

\begin{abstract}
Objective: To investigate the efficacy of core-stabilization exercise (SE) and to compare it with home-based conventional exercise (HE) in patients with chronic low-back pain (LBP).

Material and Methods: The study was performed with 48 female chronic LBP patients who attended to our outpatient unit. The patients were randomized into SE $(n=24)$ and home-based HE $(n=24)$ groups. The patients in the SE group participated in sessions of supervised group exercise for 6 weeks, 3 times a week and 60 minutes a day. The patients in the $\mathrm{HE}$ group were told to do daily conventional exercises for 6 weeks, and they were checked by telephone calls. The patients were assessed before and after the program at the third month with the visual analogue scale (VAS), Rolland-Morris Disability Questionnaire (RM), SF-36, Kraus-Weber test (KW), Sorensen test (ST), and timed sit to stand test (TSS).

Results: Following the exercise program, there was improvement in all of the variables in the SE group. In the HE group, there was also improvement in all of the variables, except ST and SF-36 pain and social function. When the groups were compared with each other, the SE group was superior to the HE group in the improvement of ST and SF-36 physical function.

Conclusion: Though both of the exercise programs were both found to be effective concerning the areas of pain, endurance, function, and daily living in patients with chronic LBP, the SE group was superior to the HE group in the endurance of dorsal extensors and in the improvement of physical role limitation.
\end{abstract}

Key Words: Activities of daily living, exercise, low back pain
Özet

Amaç: Kronik bel ağrılı hastalarda Core stabilizasyon egzersizi (SE) etkinliğini araştırmak ve konvansiyonel ev egzersiz (EE) programı ile karşılaştırmaktır.

Gereç ve Yöntemler: Çalışma, polikliniğimize başvuran kronik bel ağrılı hastalardan 48 kadın hasta ile yapıldı. Hastalar SE $(n=24)$ ve EE $(n=24)$ olmak üzere 2 gruba randomize edildiler. SE grubundaki hastalar, 6 hafta süreyle haftada 3 gün ve günde $60 \mathrm{dk}$ olmak üzere süpervizör eşliğinde toplu egzersiz seanslarına katıldılar. EE grubuna ise, 6 hafta boyunca günlük konvansiyonel ev egzersizleri yapmaları söylendi ve telefon görüşmeleriyle yapıp yapmadıkları kontrol edildi. Hastalar egzersiz programından önce ve sonra olmak üzere 3. ay sonunda Vizüel Analog Skala (VAS), Roland -Morris Dizabilite Anketi (RM), SF36, Kraus-Weber testi (KW), Sorensen testi ve zamanlı oturup kalkma testi (TSS) ile değerlendirildiler.

Bulgular: Tüm hastalar programı tamamladı. SE grubunda egzersiz sonrası tüm parametrelerde; VAS, RM, KW, Sorensen testi, TSS ve SF36 alt gruplarının tümünde iyileşme gözlendi. EE grubunda Sorensen testi ile SF-36 ağrı ve sosyal fonksiyon skorları dışındaki tüm parametrelerde düzelme saptandı. Gruplar fark skorlarıyla karşılaştıııldığında, SE grubu Sorensen testi ve SF-36 fiziksel rol kısıtlaması skorları bakımından EE grubuna göre üstün bulundu.

Sonuç: Kronik bel ağrılı kadın hastalarda her iki egzersiz programı da endurans, fonksiyon ve günlük yaşam aktivitelerini iyileştirmede etkili bulunurken, iki grup kıyaslandığında; SE grubu dorsal ekstansör kas enduransı ve fiziksel rol kısıtlaması parametrelerindeki iyileşme bakımından EE grubuna göre üstün bulundu.

Anahtar Kelimeler: Bel ağrısı, egzersiz, günlük yaşam aktiviteleri 


\section{Introduction}

Low back pain (LBP) is a frequent cause of disability in population, with up to $80 \%$ sufferers describing at least one recurrence (1). It can be acute or chronic. Chronic low back pain persists for at least 3-6 months, and it may recur in intervals rather than maintaining a continuous presence and including information on the way in which it might interrupt functioning, well-being, and quality of life (2). Strengthening of the abdominal and trunk muscles (core stabilization training) has become the treatment of choice recently (3-6). Nevertheless, some studies have shown stabilization exercises to be no better than conventional physiotherapy (7) or aerobic exercise $(6,8)$.

Individuals with LBP have been found to have greater trunk muscle activity compared to asymptomatic individuals during trunk movements in the frontal, sagittal, and transverse planes. This increase in trunk muscle activity is associated with greater trunk stiffness, angular deformation, and tissue strain, which can get better after a postural exercise program $(9,10)$.

Segmental control is an essential component for spinal stability. Current approaches to core stabilization exercise focus on the management of the control of the trunk muscles with the purpose of regaining the function of the deep intrinsic muscles of the lumbar spine and pelvis and then integration of the activity of the deep and superficial trunk muscles in functional tasks (11).

Transversus abdominis and lumbar multifidus are the two local and deep intrinsic lumbopelvic muscles that have received attention in this specific exercise modality. The transversus abdominis muscle fibers have a horizontal orientation with minimal ability to move the spine but feature in trunk rotation $(12,13)$. Spinal control involves modulation of intraabdominal pressure (IAP) and tensioning of the thoracolumbar fascia, and former data confirm that spinal stiffness is increased by IAP $(14,15)$. The multifidus can control intervertebral motion by generation of intervertebral disc pressure with minimal extension moment (16).

The efficacy of training the transversus abdominis $(\operatorname{Tr} A)$ and multifidus muscles in the treatment of acute or chronic LBP is the central question in the use of this type of exercise. Hides (17) and Sullivan (18) achieved some positive results in their studies. However, there has been a limited number of controlled studies about the efficacy of these exercise programs compared with other types of therapeutic exercise, and some of the more recent studies have shown results that are not as favorable $(19,20)$.

Though conventional exercise has been shown to be of value in the management of chronic LBP (21), the effects of core stabilization exercises remain unclear (22). The hypothesis is that the coordinated activity of the deep spinal muscles plays an important role in the intersegmental motion of the spine and pelvis. Accordingly, this randomized controlled study was done in order to put out the outcomes of the LBP patients who performed one of these two kinds of exercises for 6 weeks and determine if core stabilization exercise is better than home-based conventional exercise.

\section{Material and Methods}

\section{Subjects}

The study was done at the outpatient unit of our department. The inclusion criterion was that the patient should have chronic low back pain lasting for a minimum of 6 months leading to disability. Patients were diagnosed with a physical examination, laboratory analysis, and imaging techniques, such as $\mathrm{X}$ ray or MRI scans, and excluded if they were found to have active peripheral arthritis, spinal surgery or failed back surgery, new motor or neurologic deficit, systemic infection, cardiovascular/ pulmonary disorder with contraindication to exercise, red flags suggesting spinal pathology (23), pregnancy or unwillingness to do exercise, recent spinal stabilization, or therapeutic treatment in the last 6 weeks. Because the majority of the patients with low back pain was female and to exclude the sex factor, 64 female patients were assessed for eligibility. The patients were examined by imaging techniques, and all of them were seen to have spondylosis or discopathy or both of them with various degrees. Nine patients told that they had physical therapy treatments with or without exercise in the last 6 weeks, but they still had persisting pain. One patient had a new osteoporotic fracture, 2 patients had high white blood cell count with suspicion of infection or systemic disorder, 3 patients had spinal surgery in the last years, and 1 patient was unwilling to do exercise. Therefore, these 16 patients were excluded and given prophylactic therapeutic offers or medicine or directed for advanced search. None of the patients had done spinal stabilization exercise before. The remaining 48 low back pain (LBP) patients meeting the inclusion criterion were allocated into two treatment groups: conventional home-based exercise (HE) and lumbar core stabilization exercise (SE) groups, each consisting of 24 patients. Patients were told not to use any analgesic or nonsteroidal anti-inflammatory drugs for the study duration. Evaluations were done before treatment and at the third month by a physician blinded to the study design.

This medical research was done according to the ethical principles of the Helsinki Declaration. The hospital ethics committee approval and the patient's written informed consent were obtained.

\section{Assignment}

Participants were randomly assigned to the SE and HE groups by an independent researcher. Simple randomization was performed using a computer-generated table of random numbers. No stratification or blocking was done during the randomization procedure.

\section{Masking}

In this single-blind study, a blind examiner carried out all outcome assessments. The statistician was unaware of treatment allocations until the analysis was complete.

\section{Intervention}

Patients in the HE group ( $n=24)$ were instructed to do lumbar isometric and lumbar flexion-extension exercises, 1x20 repetitions a day for 6 weeks (standardized home-based exercise 
program for LBP patients given in the outpatient unit), and their adherence to the program was checked by telephone calls twice a week. Patients in the SE group $(n=24)$ joined a supervised (physiotherapist) group exercise program 3 times a week and for a duration of 6 weeks. The lumbar stabilization exercise program consisted of warming (5 minutes), stretching (5 minutes), stabilization exercises for the multifidus/transversus abdominis muscles (30 minutes), and cooling (5 minutes), for a total of 45-60 minutes a day.

Blood pressure and radial pulse of the subjects were checked before and after the therapy. The patients were warned of cardiac symptoms (chest pain, dizziness and dyspnea, and abnormal lumbar pain during the exercise program) and told to stop and tell the supervisor (24).

\section{Laboratory Analysis}

Routine serum and urinary biochemical analysis, hemograms, and erythrocyte sedimentation rates (ESRs) of the patients were examined at the beginning and at the end of the study in order to be aware of a systemic, metabolic, or active disease. Routine laboratory analyzers (Abbott Alcyon 300i, Advia Centaur) were used for the measurements. Blood and urine samples were collected between 8:00 and 10:00 AM after a 12-hr fast.

\section{Outcome Measures}

Daytime pain intensity was measured by a linear scale from 0 (no pain) to 10 (very bad), which is called the visual analog scale (VAS) (25).

Endurance of the abdominal muscles and dorsal extensors was measured by Krause-Weber and Sorensen tests, respectively $(26,27)$. The Krause-Weber test is performed lying back, knees in extension, and hands joined at the back of the neck. The upper body must be lifted 25 degrees from the ground and must keep the position for the evaluation of the upper abdominal muscles. In the second part, in which lower abdominal muscles are evaluated, the upper body must be lifted 25 degrees from the ground while the hands are in the same position, hips and knees are in flexion, and feet are on the ground. The time for keeping the positions is recorded as seconds. The mean value is taken for the assessment.

In the Sorensen test, a patient lies in the prone position while the upper body is overhanging and lower extremities are fixed on the bed, and the patient is told to lift her upper body parallel to the bed and keep still as much as she can. Time is recorded as seconds.

Functional ability is evaluated by timed sit to stand test (TSS). The subject is asked to stand up from a sitting position and then sit down again 5 times as quickly as possible, without using a support or shoes. Time is recorded as seconds (28).

Quality of life is evaluated by using a general scale: Short Form Health Survey (SF-36) (29-31). SF-36 comprises 36 items selected from a larger pool of items used in the Medical Outcomes Study. The SF-36 assesses 8 health concepts by using multi-item scales: physical functioning (SF-36PF) (10 items), role limitations caused by physical health problems (SF-36PRL) (4 items), role limitations caused by emotional problems (SF36ERL) (3 items), social functioning (SF-36SF) (2 items), mental health (SF-36MH) (5 items), vitality (SF-36 vitality) (4 items), pain (SF-36P) (2 items), and general health perceptions (SF36GHP) (5 items). An additional single item assesses change in perceived health. The first 4 concepts are physical component scores, and the last 4 concepts are mental component scores. The scores are between 0 and 100 (the higher the score, the better the health quality).

The Roland-Morris Disability Questionnaire, consisting of 24 items, is modified from the Sickness Impact Profile (SIP). Total score is the sum of the answers in which yes $=1$ and no=0 (32).

Adaptations to the native language of the patients have been shown to be valid and reliable for SF-36 (31) and the RolandMorris Disability Questionnaires (32).

\section{Statistical Analysis}

The statistical analyses were done with SPSS version 13.0. Shapiro-Wilk test was used to test the normality of variables. Since the data were not normally distributed, Mann-Whitney U-test was used to determine whether any differences existed among the initial values of the groups for the variables age, VAS, Krause-Weber and Sorensen tests, TSS, Roland-Morris, and SF36. Because the body mass index (BMI) in both of the groups was normally distributed, student t-test was used to determine whether any differences existed among the initial BMI values of the groups. Since the data were not normally distributed, Wilcoxon signed-rank test was used for the within-group comparisons. Comparison of the groups in terms of changes in scores and percentage changes were done by Mann-Whitney U-test. Mean \pm standard deviation or median and minimum-maximum values were given as descriptive statistics. The level of significance for all tests was taken as $\alpha=0.05$.

\section{Results}

Forty-eight voluntary female low back pain patients were enrolled in this study and randomized into the SE $(n=24)$ and HE $(n=24)$ groups with a median age of 48 (36-43) and 51 (25-64), respectively. At baseline evaluation, the groups were determined to be homogeneous for patient characteristics and clinical measurements, with the exception of Kraus-Weber duration and SF-36 physical role limitations, which were better in the HE group, respectively $(p=0.02, p=0.003)$ (Table 1$)$. All of the patients completed the program, and none of the patients had radicular pain. Two subjects in the SE group and 3 subjects in the HE group missed some of the exercise sessions (2 subjects in SE group did not attend 1 to 3 sessions, and 3 patients in the HE group told that they forgot or did not desire to do their home exercises every day, missing 2 to 3 days), but all of the participants were included in the statistical analysis, regardless of attendance irregularities.

At the third month following the exercise program, VAS, Roland-Morris score, Sorensen test, Krause Weber test, timed sit to stand test, SF-36 physical function, SF-36 physical role limitations, SF-36 pain, SF-36 social function, SF-36 mental health, SF36 emotional role limitations, SF-36 vitality, and SF-36 general health were found to be improved in the SE group. In the HE group, VAS, Roland-Morris test score, Krause Weber test, timed 
Table 1. Baseline clinical characteristics of the patients in the core stabilization exercise (SE) and home-based conventional exercise (HE) groups

\begin{tabular}{|c|c|c|c|}
\hline & $\begin{array}{l}\text { SE group } \\
(n=24)\end{array}$ & $\begin{array}{l}\text { HE group } \\
(n=24)\end{array}$ & $\underset{\text { value }}{p}$ \\
\hline $\begin{array}{l}\text { Age (years) } \\
\text { (median (min-max)) }\end{array}$ & $48(36-63)$ & $51(25-64)$ & 0.121 \\
\hline $\begin{array}{l}\text { BMI } \\
(\text { mean } \pm S D)\end{array}$ & $29.16 \pm 5.37$ & $30.28 \pm 5.78$ & 0.489 \\
\hline $\begin{array}{l}\text { VAS } \\
\text { (median (min-max)) }\end{array}$ & $6(4-9)$ & $6(1-10)$ & 0.332 \\
\hline $\begin{array}{l}\text { Roland-Morris score } \\
\text { (median (min-max)) }\end{array}$ & $15(5-19)$ & $13(3-20)$ & 0.187 \\
\hline $\begin{array}{l}\text { Sorensen test (sec) } \\
\text { (median (min-max)) }\end{array}$ & $12(5-23.83)$ & $15(9-30)$ & 0.066 \\
\hline $\begin{array}{l}\text { Kraus-Weber test (sec) } \\
\text { (median (min-max)) }\end{array}$ & $4(0-23)$ & $15(2-51)$ & 0.002 \\
\hline $\begin{array}{l}\text { Timed sit to stand test (sec) } \\
\text { (median (min-max)) }\end{array}$ & $13(9-28.41)$ & $14(9-20)$ & 0.122 \\
\hline $\begin{array}{l}\text { SF-36-physical function } \\
\text { (median (min-max)) }\end{array}$ & $45(20-85)$ & $65(15-80)$ & 0.094 \\
\hline $\begin{array}{l}\text { SF-36-role limitations (ph) } \\
\text { (median (min-max)) }\end{array}$ & $5(0-25)$ & $5(0-100)$ & 0.003 \\
\hline $\begin{array}{l}\text { SF-36-pain } \\
\text { (median (min-max)) }\end{array}$ & $40(20-60)$ & $40(20-80)$ & 0.402 \\
\hline $\begin{array}{l}\text { SF-36-social function } \\
\text { (median (min-max)) }\end{array}$ & $63(13-100)$ & $75(25-100)$ & 0.078 \\
\hline $\begin{array}{l}\text { SF-36-mental health } \\
\text { (median(min-max)) }\end{array}$ & $60(16-80)$ & $52(8-100)$ & 0.245 \\
\hline $\begin{array}{l}\text { SF-36-role limitations (e) } \\
(\text { median(min-max)) }\end{array}$ & $2(0-100)$ & $1(0-100)$ & 0.428 \\
\hline $\begin{array}{l}\text { SF-36-Vitality } \\
\text { (median (min-max)) }\end{array}$ & $30(0-80)$ & $40(10-80)$ & 0.351 \\
\hline $\begin{array}{l}\text { SF-36-general health } \\
(\text { median (min-max)) }\end{array}$ & $42(29-79)$ & $50(8-83)$ & 0.909 \\
\hline
\end{tabular}

VAS: visual analog scale; BMI: body mass index; ph: physical; e: emotional; sec: seconds; SD: standard deviation; min: minimum; max: maximum

sit to stand test, SF-36 physical function, SF-36 physical role limitations, SF-36 mental health, SF-36 emotional role limitations, SF-36 vitality, and general health also improved at the 3-month evaluation (Table 2).

When the groups were compared by changes in scores and percentage of changes, improvement was observed in the Sorensen test $(p=0.031)$ and SF-36 physical role limitations $(p=0.041)$ in favor of the SE group at the third month (Table 3).

\section{Discussion}

This study was planned to evaluate pain and endurance of the abdominal and lumbar extensor muscles in addition to daily living activities in chronic LBP patients who performed core stabilization and conventional home-based exercises. There was significant remission in the SE group in all of the variables of pain, function, endurance, and daily living. In the HE group, significant remission was also detected in all of the variables,

\begin{tabular}{|c|c|c|c|c|}
\hline & & $\begin{array}{c}\text { initial } \\
(\text { median } \\
(\text { min-max }))\end{array}$ & $\begin{array}{l}3^{\text {rd }} \text { month } \\
(\text { median } \\
(\text { min-max }))\end{array}$ & $\begin{array}{c}\mathbf{p} \\
\text { value }\end{array}$ \\
\hline \multirow[t]{2}{*}{ VAS } & SE & $6(4-9)$ & $4(0-8)$ & $<0.001$ \\
\hline & $\mathrm{HE}$ & $6(1-10)$ & $5(0-8)$ & 0.007 \\
\hline \multirow[t]{2}{*}{ Roland-Morris Score } & SE & $15(5-19)$ & $12(1-18)$ & 0.001 \\
\hline & $\mathrm{HE}$ & $13(3-20)$ & $9(0-18)$ & 0.005 \\
\hline \multirow[t]{2}{*}{ Sorensen test (sec) } & SE & $12(5-23.83)$ & $23.68(10.32-49.35)$ & $<0.001$ \\
\hline & $\mathrm{HE}$ & $15(9-30)$ & $15(8-64)$ & 0.242 \\
\hline \multirow[t]{2}{*}{ Kraus-Weber test (sec) } & SE & $4(0-23)$ & $8.56(0-25.76)$ & 0.044 \\
\hline & $\mathrm{HE}$ & $15(2-51)$ & $15(1-64)$ & 0.030 \\
\hline \multirow{2}{*}{$\begin{array}{l}\text { Timed sit to stand test } \\
(\mathrm{sec})\end{array}$} & SE & $13(9-28.41)$ & $9(5.46-22.04)$ & $<0.001$ \\
\hline & $\mathrm{HE}$ & $14(9-20)$ & $11(8-13)$ & $<0.001$ \\
\hline \multirow[t]{2}{*}{ SF-36-physical function } & SE & $45(20-85)$ & $60(15-95)$ & 0.042 \\
\hline & $\mathrm{HE}$ & $65(15-80)$ & $65(15-90)$ & 0.049 \\
\hline \multirow{2}{*}{$\begin{array}{l}\text { SF-36-role limitations } \\
\text { (ph) }\end{array}$} & SE & $5(0-25)$ & $25(0-100)$ & $<0.001$ \\
\hline & $\mathrm{HE}$ & $5(0-100)$ & $25(0-100)$ & 0.004 \\
\hline \multirow[t]{2}{*}{ SF-36-pain } & SE & $40(20-60)$ & $50(30-100)$ & 0.001 \\
\hline & $\mathrm{HE}$ & $40(20-80)$ & $40(10-100)$ & 0.251 \\
\hline \multirow[t]{2}{*}{ SF-36-social function } & SE & $63(13-100)$ & $75(25-100)$ & 0.027 \\
\hline & $\mathrm{HE}$ & $75(25-100)$ & $75(25-100)$ & 0.343 \\
\hline \multirow[t]{2}{*}{ SF-36-mental health } & SE & $60(16-80)$ & $68(40-88)$ & 0.007 \\
\hline & $\mathrm{HE}$ & $52(8-100)$ & $68(20-96)$ & 0.011 \\
\hline \multirow[t]{2}{*}{ SF-36-role limitations (e) } & SE & $2(0-100)$ & $33(0-100)$ & 0.006 \\
\hline & $\mathrm{HE}$ & $1(0-100)$ & $67(0-100)$ & 0.014 \\
\hline \multirow[t]{2}{*}{ SF-36-Vitality } & SE & $30(0-80)$ & $50(25-85)$ & $<0.001$ \\
\hline & $\mathrm{HE}$ & $40(10-80)$ & $55(15-80)$ & 0.002 \\
\hline \multirow[t]{2}{*}{ SF-36-general health } & SE & $42(29-79)$ & $50(21-79)$ & 0.043 \\
\hline & HE & $50(8-83)$ & $50(29-88)$ & 0.002 \\
\hline
\end{tabular}

VAS: visual analog scale; ph: physical; e: emotional; sec: seconds; min: minimum; max: maximum

except some endurance and pain scores. Though initial scores of SF-36 physical role limitations were better in the HE group, within-group comparisons showed higher significance in the SE group. On the other hand, the question 'Could this baseline variation affect the results on behalf of SE group?' must be kept in mind because of the reason that 'the much limitation means the more amelioration'. When the groups were compared with each other, endurance of erector spinae muscles and physical role limitations were found to be better in the core stabilization exercise group. Thus, we found evidence to support our hypothesis that SE may be better than HE in patients with LBP.

Similar to our study, França et al. (33) compared the efficacy of two exercise programs-segmental stabilization and superficial strengthening of abdominal and trunk muscles-on pain, func- 


\begin{tabular}{|c|c|c|c|}
\hline & SE (median (min-max)) & HE (median (min-max)) & $\mathrm{p}$ value \\
\hline VAS & $-2[(-7)-(1)]$ & $-1[(-10)-(2)]$ & 0.385 \\
\hline Roland-Morris & $-1[(-18)-(7)]$ & $-2[(-18)-(3)]$ & 0.779 \\
\hline Kraus-Weber test (sec) & $0[(-0.41)-(2.22)]$ & $0.25[(-0.58)-(5.80)]$ & 0.471 \\
\hline Timed Sit to Stand test (sec) & $-0.22[(-0.46)-(0.09)]$ & $-0.20[(-0.60)-(-0.07)]$ & 0.733 \\
\hline SF-36-pain & $20[(-10)-(60)]$ & $10[(-30)-(50)]$ & 0.053 \\
\hline SF-36-social function & $12[(-25)-(50)]$ & $0[(-25)-(25)]$ & 0.176 \\
\hline SF-36-mental health & $12[(-16)-(28)]$ & $20[(-32)-(36)]$ & 0.133 \\
\hline SF-36-role limitations (e) & $2[(-33)-(100)]$ & $3[(-67)-(100)]$ & 0.897 \\
\hline
\end{tabular}

VAS: visual analog scale; ph: physical; e: emotional; sec: seconds; min: minimum; max: maximum

tional disability, and activation of the TrA muscle in individuals with chronic low back pain. Both techniques resulted in pain amelioration and reduced disability. Segmental stabilization was superior to superficial strengthening for all variables, and superficial strengthening was unable to improve TrA activation capacity. Exercise programs vary in terms of duration, frequency, and dosage; whether they are supervised; and whether they include a home-based exercise program. In a systematic review of Hayden et al. (34), it is reported that individually designed exercise programs, including stretching or strengthening with supervision, may improve pain and function in chronic low back pain. Pain amelioration was found for individually designed exercise programs, supervised home-based exercise, and group exercise when compared with home exercises only. High-intensity exercise programs fared better than low-dose exercise programs, and interventions that included additional conservative care were better. These results are nearly compatible with those from a meta-analysis on the effectiveness of exercise for low back pain published in 2010 (35). In this meta-analysis, pooled data showed small but significant effects of exercise on pain and disability when compared with minimal care and no treatment and no advantage when compared with other conservative treatments. However, it is highlighted that moderate to high levels of heterogeneity suggest that pooling of trials across different types of exercise might not be ideal, and the effectiveness of specific types of exercise should not be ruled out.

Many studies report impairment of motor control in acute and chronic LBP patients. Differential changes in the activity of deep and superficial muscles have been relatively consistent in trunk motion. There is evidence of delayed activity of TrA in association with rapid limb movements in chronic LBP (36). Tonic activity of $\operatorname{TrA}$, which is normally observed during repetitive trunk and limb movements, is reduced during experimental pain, and inessential relative EMG activity of the rectus abdominis is observed in chronic LBP (37).
During functional tasks, there is reduced amplitude of activity of the multifidus in chronic LBP, and impaired responses have been observed during loading of the trunk. For example, when a load is unexpectedly dropped into the hands, there is normally a short latency response of the paraspinal muscles in healthy controls (38). When people with low back pain catch a load that is predictable, the early response of the paraspinal muscles does not occur (39). Delayed responses (40) or no change (41) in paraspinal activity may be a consequence of the altered use of the muscle. Another finding was the sustained activity of the erector spinae muscles at the end of the range of spinal flexion, a point at which the erector spinae muscles are normally inactive as the relaxation response (42).

From the evidence presented above, the component of movement that is impaired in normal function is the activity of the deep muscle system. Therefore, the focus of initial stages of rehabilitation must be to train this component independently from superficial muscles. In contrast to these articles, a critical review revealed some results that core stability exercises are no more effective than other forms of exercise or physical therapy and will not prevent injury more than any other therapeutic options. In addition, it is emphasized that any therapeutic response may be related to general exercise effects rather than stability issues (43).

\section{Conclusion}

In this study, core stabilization exercises and home-based conventional exercises for the lumbar region were both found to be effective in the remission of pain, function, endurance, and activities of daily living in the chronic LBP patients. But, a significant difference was determined in the endurance of erector spinae muscles by Sorensen test and SF-36 physical role limitations in favor of the SE group when compared with the HE group at the third month. Nevertheless, there are some limitations concerning the exercise groups and short follow-up period. The 
study groups were relatively small, consisting of middle-aged females; thus, long-term compliance with a larger number of elderly people, consisting of male patients, might give much more substantial evidence in this type of study. Therefore, specific modes of exercises, like core-stabilization training, must be studied and questioned in LBP patients in light of the foregoing research evidence.

Ethics Committee Approval: Ethics committee approval was received for this study from the ethics committee of Uludağ University Faculty of Medicine.

Informed Consent: Written informed consent was obtained from patients who participated in this study.

Peer-review: Externally peer-reviewed.

Author Contributions: Concept - A.A.; Design - A.A.; Supervision - A.A.; Funding - A.A.; Materials - A.A.; Data Collection and/or Processing - G.M., A.H.A., M.M.; Analysis and/or Interpretation - A.A., D.S.; Literature Review - A.A., G.M.; Writer - A.A.; Critical Review - A.A., G.M., A.H.A., M.M.; Other - A.H.A., M.M., D.S.

Acknowledgements: We are grateful to all of the hospital staff, especially to physiotherapists for their tremendous effort in this study.

Conflict of Interest: No conflict of interest was declared by the authors.

Financial Disclosure: The authors declared that this study has received no financial support.

Etik Komite Onayı: Bu çalışma için etik komite onayı Uludağ üniversitesi Tıp Fakültesi'nden alınmıştır.

Hasta Onamı: Yazılı hasta onamı bu çalışmaya katılan hastalardan alınmıştır.

\section{Hakem değerlendirmesi: Dış bağımsız.}

Yazar Katkıları: Fikir - A.A.; Tasarım - A.A.; Denetleme A.A.; Kaynaklar - A.A.; Malzemeler - A.A.; Veri toplanması ve/ veya işlemesi - G.M., A.H.A., M.M.; Analiz ve/veya yorum - A.A., D.S.; Literatür taraması - A.A., G.M.; Yazıyı yazan - A.A.; Eleştirel Inceleme - A.A., G.M., A.H.A., M.M.; Diğer - A.H.A., M.M., D.S.

Teşekkür: Başta fizyoterapistler olmak üzere, bu çalışmada emeği geçen tüm hastane personeline müteşekkiriz.

Çıkar Çatışması: Yazarlar çıkar çatışması bildirmemişlerdir.

Finansal Destek: Yazarlar bu çalışma için finansal destek almadıklarını beyan etmişlerdir.

\section{References}

1. Airaksinen O, Brox JI, Cedrashi C, Hildebradt J, Klaber-Moffett J, Kovacs $\mathrm{F}$ et al. Chapter 4. European guidelines for the management of chronic nonspecific low back pain. Eur Spine J 2006;15:192300. [CrossRef]
2. Von Korff M, Crane P, Lane M, Miglioretti DL, Simon G, Saunders K, et al. Chronic spinal pain and physical-mental comorbidity in the United States: results from the national comorbidity survey replication. Pain 2005;113:331-9. [CrossRef]

3. Cairns MC, Foster NE, Wright C. Randomized controlled trial of specific spinal stabilization exercises and conventional physiotherapy for ecurrent low back pain. Spine 2006;31:670-81. [CrossRef]

4. Richardson CA, Jull GA. Muscle control-pain control. What exercises would you prescribe? Man Ther 1995;1:2-10. [CrossRef]

5. Yilmaz F, Yilmaz A, Merdol F, Parlar D, Sahin F, Kuran B. Efficacy of dynamic lumbar stabilization exercise in lumbar microdiscectomy. J Rehabil Med 2003;35:163-7. [CrossRef]

6. Emel O, Nalan C. Kor stabilizasyon Egzersizleri. Available From: http://www.turkiyeklinikleri.com/article/tr-kor-stabilizasyon-egzersizleri-60041.html.

7. Cairns MC, Foster NE, Wright C. Randomized controlled trial of specific spinal stabilization exercises and conventional physiotherapy for recurrent low back pain. Spine 2006;31:670-81. [CrossRef]

8. Koumantakis GA, Watson PJ, Oldham JA. Supplementation of general endurance exercise with stabilisation training versus general exercise only. Physiological and functional outcomes of a randomised controlled trial of patients with recurrent low back pain. Clin Biomech 2005;20:474-82. [CrossRef]

9. Van Dieen JH, Kingma I, van der Bug P. Evidence for a role of antagonistic cocontraction in controlling trunk stiffness during lifting. J Biomech 2003;36:1829-36. [CrossRef]

10. Scannell JP, McGill SM. Lumbar posture--should it and can it be modified? A study of passive tissue stiffness and lumbar position during activities of daily living. Phys Ther 2003;83:907-17.

11. Hodges PW. Core stability exercise in chronic low back pain. Orthop Clin North Am 2003;34:245-54. [CrossRef]

12. Cresswell AG, Grundström $\mathrm{H}$, Thorstensson A. Observations on intra-abdominal pressure and patterns of abdominal intra-musculer activity in man. Acta Physiol Scand 1992;144:409-18. [CrossRef]

13. Urquhart DM, Hodges PW. Differential activity of regions of transversus abdominis during trunk rotation. Eur Spine J 2005;14:393-400. [CrossRef]

14. Hodges P, Kaigle Holm A, Holm S, Ekström L, Cresswell A, Hansson T, Thorstensson A. Intervertebral stiffness of the spine is increased by evoked contraction of transversus abdominis and the diaphragm: in vivo porcine studies. Spine 2003;28:2594-601. [CrossRef]

15. Hodges PW, Cresswell AG, Daggfeldt K, Thorstensson A. In vivo measurement of the effect of intra-abdominal pressure on the human spine. J Biomech 2001;34:347-53. [CrossRef]

16. Wilke HJ, Wolf S, Claes LE, Arand M, Wiesend A. Stability increase of the lumbar spine with different muscle groups. A biomechanical in vitro study. Spine 1995;20:192-8. [CrossRef]

17. Hides JA, Jull GA, Richardson CA. Long-term effects of specific stabilizing exercises for first-episode low back pain. Spine 2001;26:243-8. [CrossRef]

18. O'Sullivan PB, Phyty GD, Twomey LT, Allison GT. Evaluation of spesific stabilizing exercise in the treatment of chronic low back pain with radiologic diagnosis of spondylolysis or spondylolysthesis. Spine 1997;22:2959-67. [CrossRef]

19. Cairns MC, Foster NE, Wright C. Randomized controlled trial of spesific spinal stabilization exercises and conventional physiotherapy for recurrent low back pain. Spine 2006;31:670-81. [CrossRef]

20. Ferreira ML, Ferreira PH, Latimer J, Herbert RD, Hodges PW, Jennings $\mathrm{MD}$, et al. Comparison of general exercise, motor control exercise and spinal manipulative therapy for chronic low back pain: $A$ randomized trial. Pain 2007;131:31-7. [CrossRef]

21. Hayden JA, van Tulder MW, Malmivaara AV, Koes BW. Meta-analysis: exercise therapy for nonspesific low back pain. Ann Intern Med 2005;142:765-75. [CrossRef] 
22. Desai I, Marshall PW. Acute effect of labile surfaces during core stability exercises in people with and without low back pain. J Electromyogr Kinesiol 2010:20;1155-62. [CrossRef]

23. Williams CM, Henschke N, Maher CG, van Tulder MW, Koes BW, Macaskill P, Irwig L. Red flags to screen for vertebral fracture in patients presenting with low-back pain. Cochrane Database Syst Rev 2013;1:CD008643.

24. Larson $E B$, Bruce RA: Health benefits of exercise in an aging society. Arch Intern Med 1987; 147:353-6. [CrossRef]

25. Sokka T. Assessment of pain in rheumatic diseases. Clin Exp Rheumatol 2005;23(5 Suppl 39):77-84.

26. Ito T, Shirado O, Suzuki H, Takahashi M, Kaneda K, Strax TE. Lumbar trunk muscle endurance testing: an inexpensive alternative to a machine for evaluation. Arch Phys Med Rehabil 1996;77:75-9. [CrossRef]

27. Ito T, Shirado O, Suzuki H, Takahashi M, Kaneda K, Strax TE. Lumbar Trunk Muscle Endurance Testing: An Inexpensive Alternative to a Machine for Evaluation. Arch Phys Med Rehabil 1996; 77:75-9. [CrossRef]

28. Bonaiuti D, Arioli G, Diana G, Franchignoni F, Giustini A, Monticone $M$, et al. SIMFER Rehabilitation treatment guidelines in postmenopausal and senile osteoporosis. Eura Medicophys 2005;41:315-37.

29. Calmels P, Béthoux F, Condemine A, Fayolle-Minon I. Low back pain disability assessment tools. Ann Readapt Med Phys 2005;48:288-97. [CrossRef]

30. Hays RD, Hahn H, Marshall G. Use of the SF-36 and other healthrelated quality of Life measures to assess persons with disabilities. Arch Phys Med Rehabil 2002;83:4-9. [CrossRef]

31. Başaran S, Güzel R, Sarpel T. Yaşam kalitesi ve sağlık sonuçlarını değerlendirme ölçütleri. Romatizma 2005;20:55-62.

32. Küçükdeveci AA, Tennant A, Elhan AH, Niyazoglu H. Validation of the Turkish version of the Roland-Morris Disability Questionnaire for use in low back pain. Spine 2001;26:2738-43. [CrossRef]

33. França FR, Burke TN, Hanada ES, Marques AP. Segmental stabilization and muscular strengthening in chronic low back pain: a comparative study. Clinics 2010;65:1013-7. [CrossRef]
34. Hayden JA, van Tulder MW, Tomlinson G. Systematic review: strategies for using exercise therapy to improve outcomes inchronic low back pain. Ann Intern Med 2005;142:776-85. [CrossRef]

35. Ferreira ML, Smeets RJ, Kamper SJ, Ferreira PH, Machado LA. Can we explain heterogeneity among randomized clinical trials of exercise for chronic back pain? A meta- regression analysis of randomized controlled trials. Phys Ther 2010;90:1383-403. [CrossRef]

36. Hodges PW, Richardson CA. Delayed postural contraction of transversus abdominis in low back pain associated with movement of the lower limb. J Spinal Disord 1998;11:46-56. [CrossRef]

37. Hodges PW, Richardson CA. Feedforward contraction of transversus abdominis is not influenced by the direction of arm movement. Exp Brain Res 1997;114:362-70. [CrossRef]

38. Moseley GL, Hodges PW, Gandevia SC. External perturbation of the trunk in standing humans differentially activates components of the medial back muscles. J Physiol 2003;547:581-7. [CrossRef]

39. Leinonen V, Kankaanpää $M$, Luukkonen $M$, Hänninen $O$, Airaksinen $\mathrm{O}$, Taimela S. Disc herniation-related back pain impairs feed-forward control of paraspinal muscles. Spine 2001;26:367-72. [CrossRef]

40. Wilder DG, Aleksiev AR, Magnusson ML, Pope MH, Spratt KF, Goel VK. Muscular response to sudden load. A tool to evaluate fatigue and rehabilitation. Spine 1996;21:2628-39. [CrossRef]

41. Zedka M, Prochazka A, Knight B, Gillard D, Gauthier M. Voluntary and reflex control of human back muscles during induced pain. J Physiol 1999;520:591-604. [CrossRef]

42. Shirado O, Ito T, Kaneda K, Strax TE. Flexion-relaxation phenomenon in the back muscles. A comparative study between healthy subjects and patients with chronic low back pain. Am J Phys Med Rehabil 1995;74:139-44.

43. Lederman E. The myth of core stability. Critical review. J Bodyw Mov Ther 2010;14:84-98. [CrossRef] 